Tricyclic overdose is more difficult to treat than barbiturate overdosage, and whereas barbiturate deaths have been declining over the last few years as a proportion of all suicidal poisonings the proportion of suicidal deaths due to tricyclic poisoning has been steadily increasing-from I per cent of all suicidal poisonings in 1965 to 9 per cent in $1974(2,3)$.

I am certainly not arguing that tricyclic drugs should be abandoned, but I do believe that their indiscriminate use, particularly but not exclusively in general practice, has probably caused more harm than it has alleviated. As Dr Shaw pointed out, there are now a number of non-tricyclic compounds which seem to be just as effective as the tricyclics, but have very much lower toxicity. It is my view that one or other of these drugs should now be the antidepressant of first choice in general practice and for the treatment of psychiatric out-patients whose medication cannot be reliably supervised. Tricyclics exemplify perfectly the adage that all drugs are dangerous but some are more dangerous than others.

Department of Psychiatry,

Colin Brewer

Queen Elizabeth Hospital,

Birmingham $\mathrm{BI}_{5}{ }_{2} \mathrm{TH}$

I. Girdwood, R. H. (1974) British Medical Fournal, $i$, 501.

2. BREWER, C. (1976) World Medicine, II(12), 37.

3. - (1976) British Medical Fournal, ii, 110.

4. Вворну, J. (1967) Archives of General Psychiatry, 17, 652.

\section{TRICYCLIC PLASMA LEVELS}

\section{DEAR SiR,}

Dr Ziegler and his colleagues (Fournal, August 1977, 131, pp I68-71) reported that plasma levels of amitriptyline and nortriptyline after administration of amitriptyline hydrochloride as a single daily dose were comparable to those achieved with a thrice daily dosage schedule, and found total tricyclic levels decreased by a modest 23 per cent during the sampling period of i i to 20 hours after the last single daily dose. Unfortunately, they used a similar sampling schedule to Braithwaite et al (I), and no plasma levels were measured during the I I hours immediately following the single daily dose, the time when the most marked changes in plasma level might have been expected from a rapidly absorbed drug.

As part of a larger study, we have recently examined (Neuropharmacology, in press) between-dose plasma level profiles of nortriptyline in the same subjects after receiving either a three-times-daily nortriptyline preparation (ro $\mathrm{mg}$ nortriptyline, $0.5 \mathrm{mg} \mathrm{flu}$ phenazine) or a once-daily preparation (30 $\mathrm{mg}$ nortriptyline, $1.5 \mathrm{mg}$ fluphenazine). With each preparation the plasma level studies were carried out after seven days medication, and samples were obtained just before and during the 8 hours following the once-daily dose and the first dose of the thricedaily regimen. Although the two preparations gave similar before-dose plasma nortriptyline levels in the individuals studied, once-daily dosing produced a slow peaking effect in five out of six subjects which was not evident on the three-times-daily regimen. In two subjects the nortriptyline concentration increased after four hours to a maximum of 300 per cent of the pre-dose concentration.

Fluctuations of this magnitude suggest there could be important therapeutic differences between oncedaily and divided dose regimens of the same rapidly absorbed drug. Thus lower than customary doses of tricyclic antidepressant, if given once-daily, may be adequate for many patients since peak plasma concentrations within the recommended steady-state therapeutic range of 50-150 $\mathrm{ng}$ per $\mathrm{ml}$ (2) may be sufficient to produce a satisfactory antidepressant effect. This would avoid the risk of a poor response, as well as toxicity, associated with the high steadystate plasma concentrations which Montgomery et al (3) found in 6r per cent of their patients on standard doses of nortriptyline.

$$
\begin{aligned}
& \text { E. R. Squibb and Sons Ltd, } \\
& \text { Regal House, } \\
& \text { Treickenham, } \\
& \text { Middlesex }
\end{aligned}
$$

A. A. Schiff

\section{H. Stevenson}

Department of Pharmacology and Therapeutics, Ninewells Hospital,

Dundee

\section{References}

I. Braithwaite, R. A., Nakra, B. R. S. \& Gaind, R. (1974) Steady-state plasma concentrations during single and multiple dosage schedules of amitriptỵline. Psychological Medicine, 4, 338-41.

2. Kragh-Sorensen, P. et al (1976) Self-inhibiting action of nortriptyline's antidepressive effect at high plasma levels: a randomized double-blind study controlled by plasma concentrations in patients with endogenous depression. Psychopharmacologia, $45,305^{-12}$.

3. Montgomery, S. A., Braithwaite, R. A. \& Grammer, J. L. (1977) Routine nortriptyline levels in treatinent of depression. British Medical Journal, $i i$. I66-7. 